\title{
Adjustment of mathematical models in the drying of cagaita pulp in foam-layer
}

\author{
Maisa Dias CAVALCANTE ${ }^{1}$, Celso Martins BELISÁRIO²* (D), Daniel Emanuel Cabral de OLIVEIRA², \\ Geisa Priscilla Araújo Gomes MAIA², Weder Nunes FERREIRA JÚNIOR ${ }^{2}$, Osvaldo RESENDE²
}

\begin{abstract}
The cagaita is a native fruit from Brazilian Cerrado region. Among conservation techniques and to increase shelf life of the fruit, foam bed drying becomes ideal. This study adjusted mathematic models of foam drying of the cagaita pulp at different temperatures to determine the net diffusion coefficient and the activation energy of this process. As the foam layer drying has a shorter drying time due to the greater exposure of the surface area to the air, it allows the application of lower dehydration temperatures, so it used $40,50,60$ and $70{ }^{\circ} \mathrm{C}$, the data observed were better fitted to the Midilli model. The net diffusion coefficient increased with temperature and the activation energy was $25.368 \mathrm{~kJ} \mathrm{~mol}^{-1}$.
\end{abstract}

Keywords: Eugenia dysenterica; activation energy; liquid diffusion.

Practical Application: The cagaita is an indigenous of the Brazilian Cerrado fruit, which can be consumed fresh or processed (as jellies, ice creams, liqueurs, and juices). Because it is very perishable, it needs to be preserved by various techniques to increase its shelf life. One technique that preserves food products is foam-layer drying. Liquid or semi-liquid foods are transformed into powder by agitation and incorporation of a foaming agent, followed by dehydration. In addition, a mathematical modeling in the drying process is able to predict moisture removal behavior, estimate drying time, energy expenditure and equipment sizing.

\section{Introduction}

The Brazilian Cerrado covers almost two million square kilometers of Brazil, and includes the states of Goias, Tocantins, Mato Grosso do Sul, Minas Gerais, Bahia, Mato Grosso, Maranhão, and Piauí. It contains a rich variety in fruits, some of which have medicinal properties, high nutritional potential, and unique flavors not found in other fruits (Klink \& Machado, 2005).

The cagaita is an indigenous of the Brazilian Cerrado fruit, which can be consumed fresh or processed (as jellies, ice creams, liqueurs, and juices). Because it is very perishable, it needs to be preserved by various techniques to increase its shelf life (Costa et al., 2017).

One technique that preserves food products is foam-layer drying. Liquid or semi-liquid foods are transformed into powder by agitation and incorporation of a foaming agent, followed by dehydration (Ng \& Sulaiman, 2018).

This drying process is recommended for products that are sensitive to heat or contain sugars, mainly because they require a shorter exposure time and lower temperatures than used in other techniques (Fernandes et al., 2014).

To simulate and obtain data on product behavior during water removal, different mathematical models are used, which are based on external variables such as temperature and relative humidity of the air during the drying process (Resende et al., 2008).

A mathematical modeling in the drying process is able to predict moisture removal behavior, estimate drying time, energy expenditure and equipment sizing (Keneni et al., 2019).
Diffusion of water during drying is a complex process that involves different mechanisms, such as molecular diffusion, capillary diffusion, surface diffusion, hydrodynamic flow, vapor diffusion, and diffusion activation energy (Goneli et al., 2009).

The objective of this work was to propose and adjust mathematical models of the foam-layer drying process of cagaita at different temperatures, and to determine the effective diffusion coefficient and activation energy for this process.

\section{Material}

Cagaita fruits were collected in the region of Montes Claros, Goiás, Brazil (16 06'20 “S and 51 $17^{\circ} 11^{\prime}$ ' W), packed in $30 \times 40 \mathrm{~cm}$ polyethylene bags, placed in thermal boxes and transported to the Laboratory of Phytochemistry of IF Goiano-Campus Rio Verde. The albumina was purchased in powder by the Naturovos trademark (Salvador do Sul, RS, Brazil) at a store specializing in raw materials for the Food Industry in Rio Verde Goiás, Brazil.

\section{Methods}

The Cagaita were then selected for size, absence of mechanical injury, and maturation stage and the chosen fruits were then sanitized in chlorinated water for $15 \mathrm{~min}$ and dried on paper towels.

The fruits were homogenized in a Toturgan ${ }^{\circledR}$ electric pulper, and the pulp was packed in $25 \times 35 \mathrm{~cm}$ polyethylene bags 
and stored in a freezer at $-18{ }^{\circ} \mathrm{C}$ until analysis. For foaming, commercial, unflavored albumin $(8 \% \mathrm{w} / \mathrm{w})$ was added to the pulp, and the mixture was then shaken with a domestic shaker brand Arno, model SX 15 for 15 min.

Approximately $100 \mathrm{~g}$ of the formed foam was added onto unperforated aluminum trays and dried in an oven, using forced air circulation at $40,50,60$, and $70{ }^{\circ} \mathrm{C}$, to determine drying kinetics.

To determine drying curves and to adjust the models, the pulp was dried to a constant mass. The water contents of the product were determined in a greenhouse at $105 \pm 3{ }^{\circ} \mathrm{C}$, in three replicates, until constant mass was reached.

The experimental data obtained from the drying of the cagaita pulp with an emulsifier were used to adjust the mathematical models frequently used to describe drying processes of vegetable products, as presented in Table 1 .

For the adjustment of the mathematical models, non-linear regression analysis (Equation 13) was performed by the Gauss Newton method.

$\mathrm{RX}=\frac{\mathrm{X}^{*}-\mathrm{X}_{\mathrm{e}}^{*}}{\mathrm{X}_{\mathrm{i}}^{*}-\mathrm{X}_{\mathrm{e}}^{*}}$

Where:

RX - moisture ratio, non-dimensional;

$\mathrm{X}^{\star}-$ moisture content, dry basis;

$\mathrm{X}_{\mathrm{e}}^{*}-$ moisture content equilibrium, dry basis;
$\mathrm{X}_{\mathrm{i}}^{*}$ - initial moisture content, dry basis.

The models were selected based on the magnitude of the coefficient of determination $\left(\mathrm{R}^{2}\right)$, the chi-squared test $\left(\chi^{2}\right)$, the mean relative error $(\mathrm{P})$, and the estimated standard deviation (SE). Additionally, an average relative error below 5\% was considered one of the criteria for the selection of models, as per (Mohapatra \& Srinivasa Rao, 2005).

To evaluate net diffusion, we used the model of the flat plate geometry with an approximation of eight terms (Equation 14), which was adjusted to the experimental data of foam-layer drying of the cagaita pulp, and we considered the surface area and volume.

$\mathrm{RX}=\frac{\mathrm{X}^{*}-\mathrm{X}_{\mathrm{e}}^{*}}{\mathrm{X}_{\mathrm{i}}^{*}-\mathrm{X}_{\mathrm{e}}^{*}}=\frac{8}{\pi^{2}} \sum_{\mathrm{n}_{\mathrm{t}}=0}^{\infty} \frac{1}{\left(2_{\mathrm{nt}}+1\right)^{2}} \exp \left[\frac{-\left(2_{\mathrm{nt}}+1\right)^{2} * \pi^{2} * \mathrm{D} * \mathrm{~T}}{4}\left(\frac{\mathrm{S}}{\mathrm{V}}\right)^{2}\right]$

Where:

$\mathrm{RX}$ - moisture ratio, non-dimensional;

$\mathrm{X}^{\star}-$ moisture content, dry basis;

$\mathrm{X}_{\mathrm{e}}^{\star}$ - moisture content equilibrium, dry basis;

$\mathrm{X}^{\star}{ }_{\mathrm{i}}$ - initial moisture content, dry basis;

nt - number of terms;

$\mathrm{S}$ - surface area, $\mathrm{m}^{2}$;

$\mathrm{V}$ - volume, $\mathrm{m}^{3}$.

Table 1. Mathematical models (Equation 1 to 12 ) applied to drying kinetics data.

\begin{tabular}{|c|c|c|}
\hline Equation & \multicolumn{2}{|l|}{ Model } \\
\hline $\mathrm{RX}=1+\mathrm{at}+\mathrm{bt}^{2}$ & Wang and Sing & (1) \\
\hline$R X=a \cdot \exp (-k t)+(1-a) \exp \left(-k_{1} t\right)$ & Verma & (2) \\
\hline $\mathrm{RX}=\exp$ & Thompson & (3) \\
\hline $\mathrm{RX}=\exp \left(-\mathrm{k} \cdot \mathrm{t}^{\mathrm{n}}\right)$ & Page & (4) \\
\hline$R X=\exp (-k . t)$ & Newton & $(5)$ \\
\hline $\mathrm{RX}=\mathrm{a} \cdot \exp \left(-\mathrm{k} \cdot \mathrm{t}^{\mathrm{n}}\right)+\mathrm{b} \cdot \mathrm{t}$ & Midilli & (6) \\
\hline$R X=a \cdot \exp (-k \cdot t)+c$ & Logarithmic & (7) \\
\hline $\mathrm{RX}=\mathrm{a} \cdot \exp (-\mathrm{k} \cdot \mathrm{t})$ & Henderson and Pabis & (8) \\
\hline$R X=a \cdot \exp (-k \cdot t)+b \cdot \exp \left(-k_{0} \cdot t\right)+c \cdot \exp \left(-k_{1} \cdot t\right)$ & Henderson and Pabis, modified & (9) \\
\hline$R X=a \cdot \exp (-k \cdot t)+(1-a) \exp (-k \cdot a . t)$ & Two-term Exponential & $(10)$ \\
\hline$R X=a \cdot \exp \left(-k_{0} \cdot t\right)+b \cdot \exp \left(-k_{1} \cdot t\right)$ & Two-term & $(11)$ \\
\hline$R X=a \cdot \exp (-k \cdot t)+(1-a) \exp (-k \cdot b \cdot t)$ & Diffusion Approximation & $(12)$ \\
\hline
\end{tabular}

$\mathrm{t}$ - time (h); k, $\mathrm{k}_{\mathrm{o}}, \mathrm{k}_{1}$ - constant of the equation $\left(\mathrm{h}^{-1}\right) ; \mathrm{a}, \mathrm{b}, \mathrm{c}, \mathrm{n}$ - parameters of the equations; $\mathrm{RX}$ - moisture ratio, non-dimensional. 
The dimensions of length, width, and thickness were measured with a digital caliper.

The relationship between the diffusion coefficient and the drying air temperature is described by Equation 15 .

$\mathrm{D}=\mathrm{D}_{0} \cdot \exp \left(\frac{-\mathrm{E}_{\mathrm{a}}}{\mathrm{R} \cdot \mathrm{T}_{\mathrm{abs}}}\right)$

Where:

$\mathrm{D}_{0}$ - Pre-exponential factor;

$\mathrm{E}_{\mathrm{a}}$ - Activation energy, $\mathrm{kJ} \mathrm{mol}^{-1}$;

$\mathrm{R}$ - Universal Gas Constant, $8.134 \mathrm{~kJ} \mathrm{kmol}^{-1} \mathrm{~K}^{-1}$;

$\mathrm{T}_{\mathrm{abs}}$ - Absolute temperature, $\mathrm{K}$.

The Arrhenius expression coefficients were log-linearized according to Equation 16.

$\ln \mathrm{D}=\ln \mathrm{D}_{\mathrm{o}}-\frac{\mathrm{E}_{\mathrm{a}}}{\mathrm{R}} \cdot \frac{1}{\mathrm{~T}_{\mathrm{abs}}}$

In addition to the previous parameters, the Akaike information criterion (AIC) and the Bayesian Schwarz information criterion (BIC) were used. The AIC allows us to use the principle of parsimony in choosing the best model, that is, according to this criterion, the most parameterized model is not always the best (Burnham \& Anderson, 2004).

AIC is used to compare non-nested models or to compare three or more models. Lower AIC values reflect a better fit (Akaike, 1973). BIC also considers the degree of parameterization of the model, and therefore, the smaller the BIC value is Schwarz (1978), the better the model adjustment is.

\section{Results and discussion}

Drying curves of cagaita foam at $40,50,60$, and $70^{\circ} \mathrm{C}$. The values were estimated from Midilli model are shown in Figure 1.

It was observed that the drying time decreases with the increase in the temperature. Ferreira et al. (2012) previously explained that due to the increase in the drying rate, the heat transfer potential between the air and the layer of the product is increased, resulting in greater water reduction in a shorter period compared with lower drying rates.

The curves have a steeper slope due to the increase in the amount of heat transferred from the air to the dried material. Similar behaviors were reported by Baptestini et al. (2015) in a study of foam drying of graviola.

As seen in Table 2, the Page model fitted better at 50, 60, and $70{ }^{\circ} \mathrm{C}$ than the other models; the Two-term Exponential fitted better at $50{ }^{\circ} \mathrm{C}$ and $70{ }^{\circ} \mathrm{C}$ than the others; and the Two-term fitted better at $70{ }^{\circ} \mathrm{C}$ than the others. In order to adjust the mathematical models, $\mathrm{P}$ must be less than $10 \%$ (Mohapatra \& Srinivasa Rao, 2005), $\mathrm{R}^{2}$ must be next to the unit, and SE must be close to zero (Resende et al., 2006).

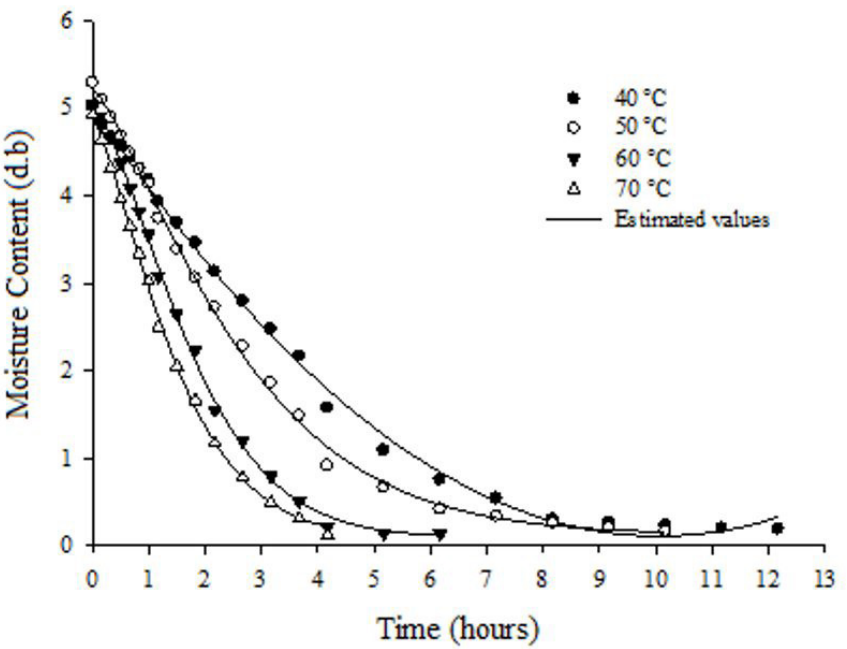

Figure 1. Foam-layer drying curves of cagaita pulp (Eugenia dysenterica DC) at different temperatures.

The Diffusion Approximation model and the Henderson and Pabis Modified model were adapted to the experimental data obtained at drying at $70{ }^{\circ} \mathrm{C}$. The Midilli model, followed by the Wang and Sing model, was the best model to represent the drying kinetics of powdered cagaita pulp at all temperatures.

The models for the same mathematical models in foam-layer drying were found by Silva et al. (2008) in the dehydration of the tamarind pulp, with temperatures between 50 and $80^{\circ} \mathrm{C}$, where the best models that represent the behavior of the dehydration curves were of Midilli and Kucuk. Alves \& Rodovalho (2016) with avocado pulp, with temperatures of 50 to $80^{\circ} \mathrm{C}$, and the best model of Wang and Sing. In Table 3, the AIC and BIC confirmed that the fit of the Wang and Sing model was better at 40 and $50^{\circ} \mathrm{C}$, whereas the Midilli model was better adjusted at 60 and $70^{\circ} \mathrm{C}$.

When analyzing the drying kinetics of the crushed jambu mass, evaluating the AIC and BIC parameters, it found the best Midilli model for temperatures of 60 and $70^{\circ} \mathrm{C}$ (Gomes et al., 2018). The Midilli model is probably associated with the rapid loss of water at the beginning of the process steps, generating a drying curve that best characterizes mathematically by this model (Goneli et al., 2009).

The values of the net diffusion obtained for the different drying temperatures are shown in Figure 2. The curve shows a linear, increasing behavior in which the values of the diffusion coefficient increased with the increase in the temperature.

According to Baptestini et al. (2015), this behavior is predictable, because the temperature is inversely correlated to the viscosity, which facilitates the diffusion of water molecules in the capillaries of the product. The same behavior was observed by Alves \& Rodovalho (2016), in their study of foam-layer drying kinetics of avocado pulp. The variation in the effective diffusion coefficient as a function of drying temperature is described by the ratio of Arrhenius (Figure 3). 
Table 2. Coefficient of determination $\left(\mathrm{R}^{2}\right)$, mean relative error $(\mathrm{P})$, and estimated standard deviation (SE) of models analyzed during the foamlayer drying of cagaita pulp.

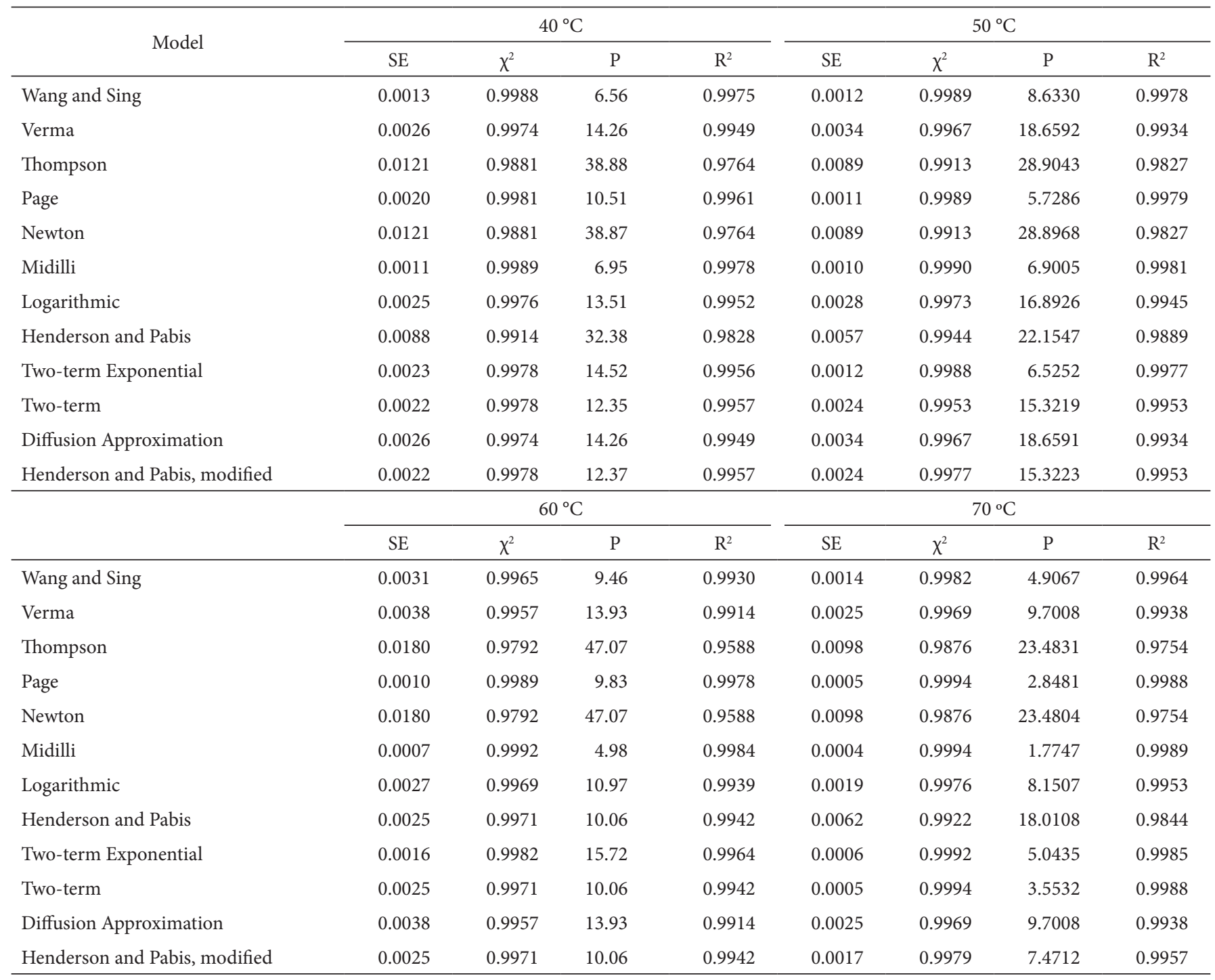

Table 3. Akaike information criterion (AIC) and Bayesian Schwarz information criterion (BIC) selection criteria of the models with best adjustments of the cagaita pulp drying kinetics at different temperatures.

\begin{tabular}{crrrr}
\hline \multirow{2}{*}{ Temperature $\left({ }^{\circ} \mathrm{C}\right)$} & \multicolumn{2}{c}{ Wang and Sing } & \multicolumn{2}{c}{ Midilli } \\
\cline { 2 - 5 } & AIC & BIC & AIC & BIC \\
\hline 40 & -101.57 & -98.583 & -100.08 & -95.105 \\
50 & -97.819 & -94.981 & -96.744 & -92.022 \\
60 & -59.796 & -57.672 & -78.389 & -74.858 \\
70 & -65.79 & -63.872 & -78.883 & -65.79 \\
\hline
\end{tabular}

The activation energy for drying the foam of the powdered cassava pulp was $25.368 \mathrm{~kJ} \mathrm{~mol}^{-1}$ at a temperature range of 40 to $70{ }^{\circ} \mathrm{C}$. Similar values were found for bananas dried by the same method (Thuwapanichayanan et al., 2008), which had an activation energy of $25.19 \mathrm{~kJ} \mathrm{~mol}^{-1}$ at a temperature range of 60,70 and $80^{\circ} \mathrm{C}$.

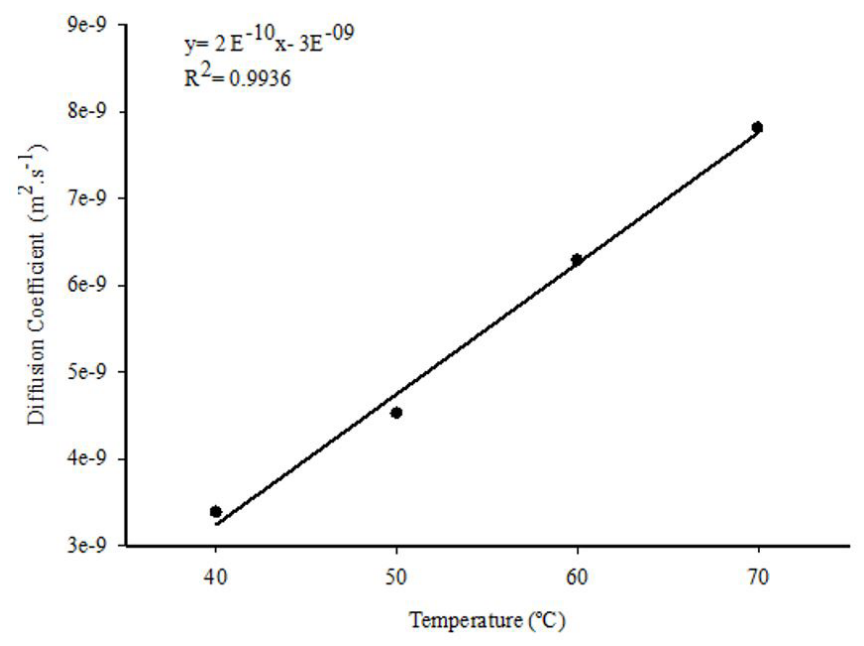

Figure 2. Diffusion Coefficient vs. temperature obtained by foam-layer drying of cagaita pulp (Eugenia dysenterica DC). 


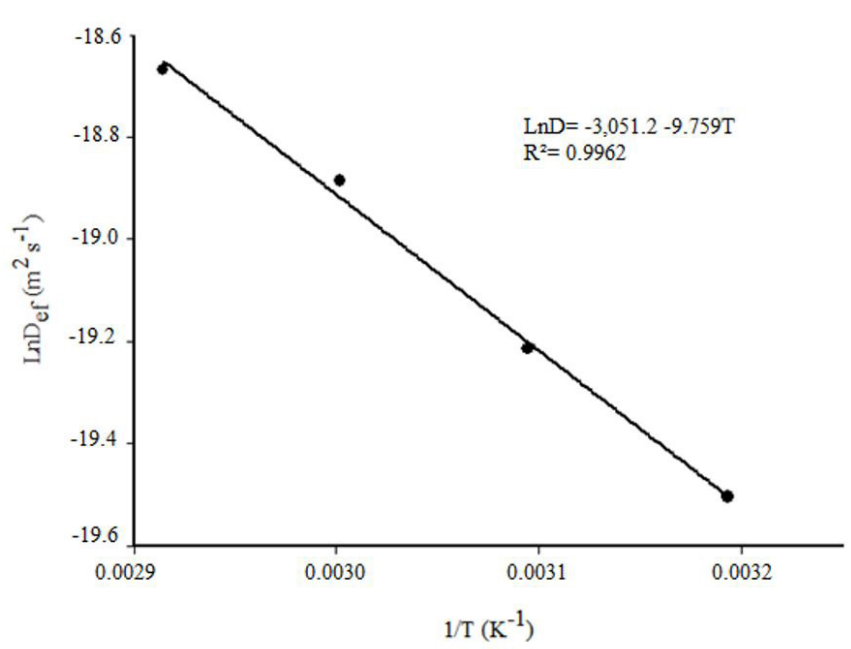

Figure 3. Arrhenius plot of cagaita foam drying at a temperature range of $40,50,60$ and $70^{\circ} \mathrm{C}$, including regression equation and its coefficient of determination.

The lower the activation energy is, the greater the water diffusivity in the product is. Our reported values are within the energy activation range reported by Zogzas et al. (1996), i.e., between 12 and $110 \mathrm{~kJ} \mathrm{~mol}^{-1}$.

\section{Conclusion}

The Wang and Sing models at 40 and $50^{\circ} \mathrm{C}$ and the Midilli model at 60 and $70{ }^{\circ} \mathrm{C}$ were the ones that best fit the experimental data of the drying curves of the foam-layer drying of cagaita using AIC and BIC parameters. With increasing air temperature, a reduction in the drying time of the cagaita pulp foam occurred. The net effective diffusion coefficient increases with increasing drying temperature. The value of the activation energy is within the established parameters.

\section{Acknowledgements}

This work was supported by FAPEG and IF Goiano-Campus Rio Verde. To Bheatriz S.M. de Freitas for supplying cagaita fruits.

\section{References}

Akaike, H. (1973). Information theory and an extension of the maximum likelihood principle. In B. N. Petrov \& F. Csaki (Eds.), Proceedings of the 2nd International Symposium on Information Theory (pp. 267-281). Budapest: Akademiai Kiado. Retrieved from https://link. springer.com/chapter/10.1007/978-1-4612-1694-0_15

Alves, J. J. L., \& Rodovalho, R. S. (2016). Cinética de secagem em camada de espuma da polpa de abacate cv 'quintal' (Persea Americana Mill). Revista Agrotecnologia, 6(1), 86-99. http://dx.doi.org/10.12971/21795959/agrotecnologia.v7n1p86-98.

Baptestini, F. M., Corrêa, P. C., Junqueira, M. S., Ramos, A. M., Vanegas, J. D., \& Costa, C. F. (2015). Modelagem matemática da secagem de espuma de graviola. Revista Brasileira de Engenharia Agrícola e Ambiental, 19(12), 1203-1208.http://dx.doi.org/10.1590/1807-1929/agriambi.v19n12p1203-1208.

Burnham, K. P., \& Anderson, D. R. (2004). Multimodel inference: understanding AIC and BIC in model selection. Sociological Methods \& Research, 33(2), 261-304. http://dx.doi.org/10.1177/0049124104268644.
Costa, L. T., Rodrigues, D. B., Melo, C. F., Souza, A. G., Garcia, E. M., Taroco, H. A., \& Melo, J. O. F. (2017). Discovering the secrets of Cagaiteira (Eugenia dysenterica), an awakening of Cerrado (Vol. 10, pp. 45-49). Rondonópolis: Scientific Electronic Archives. Retrieved from http://www.seasinop.com.br/revista/index.php?journal=SEA \&page $=$ article\&op $=$ view\&path $\% 5 B \% 5 \mathrm{D}=463 \&$ path $\% 5 \mathrm{~B} \% 5 \mathrm{D}=\mathrm{pdf}$

Fernandes, R. V. B., Queiroz, F., Botrel, D. A., Rocha, V.V., Souza, V. R., \& Lima, C. F. (2014). Estudo da adição de albumina e da temperatura de secagem nas características de polpa de tomate em pó. Ciências Agrárias, 35(3), 1267-1278. http://dx.doi.org/10.5433/1679-0359.2014v35n3p1267.

Ferreira, L. F. D., Pirozi, M. R., Ramos, A. M., \& Pereira, J. A. M. (2012). Modelagem matemática da secagem em camada delgada de bagaço de uva fermentado. Pesquisa Agropecuária Brasileira, 47(6), 855-862. http://dx.doi.org/10.1590/S0100-204X2012000600017.

Gomes PF, Resende O, Sousa EP, Oliveira DEC, Araújo FR No. (2018). Cinética de secagem da massa esmagada de 'jambu': difusividade efetiva e energia de ativação. Revista Brasileira de Engenharia Agrícola e Ambiental, 22(7), 499-505. https://dx.doi.org/10.1590/1807-1929/ agriambi.v22n7p499-505.

Goneli, A. L. D., Corrêa, P. C., Afonso, P. C. Jr., \& Oliveira, G. H. H. (2009). Cinética de secagem dos grãos de café descascados em camada delgada. Revista Brasileira de Armazenamento, 11, 64-73. Retrieved from https://www.researchgate.net/publication/258242741

Keneni, Y. G., Hvoslef-eide, A. K. T., \& Marchetti, J. M. (2019). Mathematical modelling of the drying kinetics of Jatropha curcas L. seeds. Industrial Crops and Products, 132, 12-20. http://dx.doi. org/10.1016/j.indcrop.2019.02.012.

Klink, C. A., \& Machado, R. B. (2005). Conservation of the Brazilian Cerrado. Conservation Biology, 42(3), 707-713. http://dx.doi. org/10.1111/j.1523-1739.2005.00702.x.

Mohapatra, D., \& Srinivasa Rao, P. (2005). A thin layer drying model of parboiled wheat. Journal of Food Engineering, 66(4), 513-518. http://dx.doi.org/10.1016/j.jfoodeng.2004.04.023.

Ng, M. L., \& Sulaiman, R. (2018). Development of beetroot (Beta vulgaris) powder using foam mat drying. $L W T, 88,80-86$. http:// dx.doi.org/10.1016/j.lwt.2017.08.032.

Resende O, Corrêa PC, Goneli ALD, Ribeiro DM. (2006). Isotermas e calor isostérico de sorção do feijão. Ciência e Tecnologia dos Alimentos, 26(3), 626-631. http://dx.doi.org/10.1590/S0101-20612006000300022.

Resende, O., Corrêa, P. C., Goneli, A. L. D., Botelho, F. M., \& Rodrigues, S. (2008). Modelagem matemática do processo de secagem de duas variedades de feijão (Phaseolus vulgaris L.). Revista Brasileira de Produtos Agroindustriais, Campina Grande, 10(1), 17-26. http:// dx.doi.org/10.15871/1517-8595/rbpa.v10n1p17-26.

Schwarz, G. (1978). Estimating the dimension of a model. Annals of Statistics, 6(2), 461-464. http://dx.doi.org/10.1214/aos/1176344136.

Silva, A. S., Gurjão, K. C. O., Almeida, F. A. C., Bruno, R. L. A., \& Pereira, W. E. (2008). Desidratação de polpa de tamarindo pelo método de camada de espuma. Ciência e Agrotecnologia, 32(6), 1899-1905. http://dx.doi.org/10.1590/S1413-70542008000600032.

Thuwapanichayanan, R., Prachayawarakorn, S., \& Soponronnarit, S. (2008). Drying characteristics and quality of banana foam mat. Journal of Food Engineering, 86(4), 573-583. http://dx.doi.org/10.1016/j. jfoodeng.2007.11.008.

Zogzas, N. P., Maroulis, Z. B., \& Marinos-Kouris, D. (1996). Moisture diffusivity data compilation in foodstuffs. Drying Technology, 14(10), 2225-2253. http://dx.doi.org/10.1080/07373939608917205. 